\title{
INSAN KAYNAKLARI FONKSIYONUNDA DIŞ KAYNAKLARDAN YARARLANMA /YARARLANMAMA KARARI : AKARYAKIT DAĞITIM SEKTÖRÜNDE BİR ÖRNEK OLAY
}

\author{
Göksel ATAMAN \\ Marmara Üniversitesi, İI. B.F. Issletme Bölümü, Doçent Dr.
}

\author{
WHETHER OR NOT TO OUTSOURCE HUMAN \\ RESOURCES : A CASE STUDY IN THE FUEL OIL \\ DISTRIBUTION SECTOR
}

\begin{abstract}
The fact that company services are rendered from external resources may be explained with a combination of many reasons, major of which may be listed as technological developments, globalization and increasingly growing recognition of tendency towards outsourcing.

For works to be fulfilled by HR departments, companies prefer to obtain the services of diverse subjects and levels from external sources, depending on the requirements and strategies of each company. Again depending on the company ,such services are purchased for all operations of the company or only part of them. Rules that may be used as guidance for decision-making on this matter are really rare in the literature. This study attempts to consider why outsourcing has been popular and the factors that may explain the decisions made on this matter. To this end, human resources activities of a company operating in the fuel oil industry, having 3885 filling stations, employing over one thousand employees and having a national marketing net have been studied and the level of using external resources for performing its operations has been determined.
\end{abstract}

Keywords: Human Resources Outsourcing, The Make Or Buy Decision, Fuel Oil Distribution Sector

\section{GíRiş}

Diş kaynaklardan yararlanma, işletmelerin değişen çevre koşulları ve artan rekabet ile mücadelelerinde başvurdukları bir araç niteliği taşımaktadır. Temel yetenekleri dişında kalan işleri kendi bünyesinde gerçekleştirmeyip, bunun sağlayacağı avantajlardan yararlanmayı hedefleyen işletmelerin sayısı giderek artmaktadır. Müşteri karşısında değer yaratmaya yönelik tüm faaliyetlerin, dış kaynaklar aracılığıyla sağlanabilirliği, işletmeleri bu konuda düşünmeye ve çözümler üretmeye yöneltmektedir. İşletmeler neyi, neden, nasıl yapacaklarını tekrar düşünmekte, bu

\author{
INSAN KAYNAKLARI FONKSIYONUNDA DISS \\ KAYNAKLARDAN YARARLANMA /YARARLANMAMA \\ KARARI : AKARYAKIT DAĞITIM SEKTÖR̈̈NDE BİR \\ ÖRNEK OLAY
}

Özet: Son dönemde bir çok işletme fonksiyonun dis kaynaklardan yararlanmaya konu olmast çok saytda nedenini bir araya gelmesine bağll olarak açıklanabilir. Teknolojik değişiklikler, küreselleşme, ve dıs kaynaklardan yararlanma konusunda başvurulabilecek tedarikçilerin sayısının artarak bu eğilimin giderek daha fazla kabul görmesi söz konusu nedenlerin başında gelmektedir.

Insan kaynaklarn faaliyetlerinin yerine getirilmesi surasinda firmalar farkl konularda ve farkl seviyelerde hizmeti dışartdan temin etme yoluna gitmekte, bu noktada firmanın ihtiyaçlan ile stratejileri belirleyici olmaktadır. Bu noktada tüm faaliyetlerin mi yoksa sadece bir bölümünün mü dış kaynaklardan sağlanacağl firmaya bağll olarak farklulaşmaktadır. Bu konudaki kararin nasıl verileceğine dair literatürde çok az sayıda çalışma vardır.

Bu çalışmada dış kaynaklardan yararlanmanın neden popüler hale geldiğinin açıklanmast ve bu konudaki karara ışık tutan faktörlerin açıklanması amaçlanmaktador. Bu amaç doğrultusunda akaryakut dağıtım sektöründe faaliyet gösteren, faaliyetlerini 3885 istasyonda sürdüren,binden fazla çalışana ve ulusal pazarlama ağına sahip firmantn insan kaynaklan faaliyetleri incelenerek, bu faaliyetlerin yerine getirilmesinde dis kaynaklardan yararlanma seviyesi açılanmaktadır.

Anahtar Kelimeler: Insan Kaynaklarında Dış Kaynaklardan Yararlanma, DIS Kaynaklardan Yararlanma Karartnin Verilmesi, Akaryakut Dağttum Sektörï

çerçevede yeni süreçler, ilişkiler ve işbirlikleri ve örgüt yapılanı ortaya çıkmaktadır.

$\mathrm{Bu}$ çalışmada dış kaynaklardan yararlanma, daha çok insan kaynakları fonksiyonu açısından tartışılacaktır. İnsan kaynakları yönetiminde dış kaynaklardan yararlanmanın nedenleri ortaya konulduktan sonra, insan kaynakları alanında dış kaynaklardan yararlanmanın kapsamı açıklanacaktır. İnsan kaynakları yönetiminde dış kaynaklardan yararlanma kararının verilmesine 1 şı tutan hususlar ele alındıktan sonra akaryakıt dağıtım sektöründe faaliyet gösteren bir firmanın insan kaynakları 
fonksiyonuna ilişkin faaliyetleri ve bu süreçte diş kaynaklardan yararlanma eğilimi incelenecektir.

\section{INSAN KAYNAKLARI YÖNETIMIINDE DIŞ KAYNAKLARDAN YARARLANMA VE NEDENLERİ}

İnsan Kaynakları departmanlarının dı\$ kaynaklardan sağladıkları hizmetler birbirinden farklılık göstermektedir. Tedarikçi veya tedarikçilerle ilişkiler, firmanın ihtiyaçları ve izlenen stratejilere göre şekillenmektedir [1]. Insan kaynakları fonksiyonlarının hangilerinin ve hangi seviyede $d_{1}$ ş kaynaklardan sağlanacağı önemli bir karardır.

Gerek ülkemizde gerekse dünyada insan kaynakları fonksiyonlarının giderek artan biçimde firma dışında gerçekleştirildiği bilinmektedir. Bununla amaçlanan dış kaynaklardan yararlanmanın sağlayacağı avantajları kullanarak rekabet gücünü korumak ve iyileştirmektir.

Dünyada ve ülkemizde, insan kaynaklarında dış kaynak kullanımının oranı ve kapsamı bir çok araştırmaya konu olmuştur. Alanlara dağılım, ülkelere ve araştırmalara göre farklılık göstermekle birlikte, dış kaynaklardan yararlanmanın daha çok yan ödeme uygulamaları, işe alım, eğitim ve geliştirme, İK bilgi sistemlerinin bakım ve destek işleri, değișim yönetimi alanlarında yoğunlaştığı söylenebilir. İnsan kaynakları yönetiminde, dış kaynaklardan yararlanmanın giderek yaygınlaştığ 1 ise literatürde genel kabul görmektedir.

Dış kaynaklardan yararlanma uygulamalarını ön plana çıkaran nedenler oldukça çok sayıdadır. Küreselleşmenin işletmelere önemli tehdit ve fursatlar sunduğu günümüzde işletmeler daha yalın örgüt yapılarına yönelmektedir. Diş kaynaklardan yararlanma işletmelerin yalın örgüt yapısına ulaşmasını, temel yetenekleri dışında kalan konularda emek zaman ve kaynak harcamasını engellemektedir.

Küreselleşmenin etkisiyle hılanan ve tüm sektörleri etkisi altına alan bir başka eğilim de işletmeler arası birleşme ve satın almalar 'dır. Birleșme ve devir sürecinde ve sonrasında personele ilişkin faaliyetlerin bağımsız bir tedarikçi tarafından yerine getirilmesi tercih edilmektedir [2]. Farklı firmaların kültürlerinin bir araya gelmesi ve bir arada etkin çalışma zorunluluğu insan kaynakları departmanının rol ve sorumluluklarını daha karmaşık hale getirmiştir. Diğer taraftan çalışma hayatını düzenleyen kural ve uygulamaların ülkeden ülkeye farklılık göstermesi başta olmak üzere birçok değişiklik etkin insan kaynakları yönetimine duyulan ihtiyacı arttırmaktadır [3].
Küreselleşme ve artan rekabet işletmelerin belirli standartlara uygunluğunu zorunlu kılmaktadır.

Küresel standartlara uygunluk, insan kaynağının etkin kullanıldığı ve işletmenin kaynaklarının temel yetenekler etrafında yoğunlaştırıldığı bir düzeni gerektirmektedir. Müşteri değer yaratma zincirinin tüm halkalarının tek bir işletme tarafından gerçekleştirilmeyip, her işletmenin en iyi olduğu konu ile bu zincir içinde yer alması standartları yakalamayı kolaylaştıracaktır.

Teknolojik gelişmeler de insan kaynakları uygulamaları açısından önem taşımaktadır. Bilgisayar destekli eğitim, Internet, elektronik posta gibi araçlar sayesinde bilgi ve haberlerin paylaşılması kolaylaşmakta, dış kaynaklardan yararlanma uygulamalarının başarı şansı artmaktadır. Diğer taraftan insan kaynakları fonksiyonlarının yerine getirilebilmesi için ihtiyaç duyulan teknolojik altyapı da belirli bir maliyet unsurudur. İnsan kaynakları fonksiyonlarının diş kaynaklardan sağlanması işletmelerin bu konudaki maliyetlere katlanmamasını beraberinde getirmektedir [4]. Insan kaynakları bilgi sistemleri uygulamaları tüm işlerin,süreçlerin ve departmanların yeniden tasarlanmasına, bu çerçevede dış kaynaklardan yararlanma eğiliminin yaygınlaşmasına zemin hazırlamıştır.

Dış kaynaklardan yararlanmanın yaygınlaşmasında işletmelerin karşılaştığı zaman baskısının da büyük payı vardır. Temel yeteneği insan kaynakları olan bir firmadan sağlanacak destek çoğu kez daha hızlı ve daha profesyoneldir. Bu durum özellikle eğitim ile ilgili olarak karşımıza çıkar. Danışmanlık firmaları tarafından önceden üzerinde düşünülerek hazırlanmış, başarısı kanıtlanmış, zaman kaybetmeden uygulanabilecek paket eğitim programları firmaya etkin sonuçlar sağlayacaktır. İşletmenin aynı anda çok sayıda eleman istihdam etmesi gerektiği durumda, işe alma ve yerleştirme konusunda diş kaynaklardan yararlanılması mantıklıdır [5].

Maliyet baskısı da dış kaynaklardan yararlanma uygulamalarının önemli bir nedendir. Temel yeteneği üzerinde odaklaşan firma uzmanlaşma ile birlikte ölçek ekonomisinden yararlanma imkanı bulacak, belirli bir mal ya da hizmetin daha ucuza sunulması mümkün olacaktır. Maliyetleri önemli ölçüde azaltan bir uygulama olarak dış kaynaklardan yararlanma, büyük bir sabit maliyet artı değişken maliyet yapısından, tamamen değişken bir maliyet yapısına geçişi sağlamaktadır. Risk yönetimine de katkısı olan bu sistem hem maliyet hem de teknoloji ve yatırım risklerini ortadan kaldırmakta,yanlış teknoloji ve süreçleri engellemektedir [6].

Dış kaynaklardan yararlanmanın maliyet avantajı yaramamasının da zaman zaman söz konusu olduğu belirtilmelidir. Büyük işletmelerde insan kaynakları faaliyetlerinin belirli bir hacmin üzerinde olması ölçek 
ekonomisinden yararlanmayı sağlamakta, bu ise diş kaynaklardan yararlanmanın getireceği maliyet avantajını ortadan kaldırmaktadır. Yine diş kaynaklardan yararlanma, bu hizmeti sağlayan firmaların sayıca az olduğu durumda,diğer deyişle tedarikçiye bağımlılığın mevcut olduğu durumda beklenen maliyet avantajını sağlamayabilir [5].

Fason ve taşeron kullanma mantığından farklı olarak kalitenin ve uzun dönemli, her iki tarafında kazanmasına yönelik anlayışın daha hakim olduğu, stratejik ortaklık mantığında yürütülen dıș kaynaklardan yararlanma uygulamalarında maliyet avantajının ikinci planda tutulması gerektiği belirtilmelidir. Bu durum tüm dış kaynaklardan yararlanma uygulamaları için geçerli olup, insan kaynakları uygulamalarında daha da ön plana çıkmaktadır. Müşteri memnuniyetinin temelinde çalışan memnuniyetinin yer aldığı unutulmamalıdır.

Dağınık verileri tek merkezde toplamak, gizliliğin korunmasını sağlamak da insan kaynaklarında dış kaynaklardan yararlanmanın tercih edilme nedenleri arasında belirtilebilir.

\section{INSAN KAYNAKLARI YÖNETIMINDE DIŞ KAYNAKLARDAN YARARLANMANIN KAPSAMI}

İnsan kaynaklarında dış kaynak olarak hizmet sağlayan çok sayıda firma mevcuttur. Bu firmalar danışmanlık firması gibi değil, şirketin içinde bir bölüm gibi hizmet vermektedir. Firmaların sundukları hizmetler tüm insan kaynakları fonksiyonlarını içermektedir. Hizmet alanlar;

- Insan kaynakları departmanının oluşturulması, dinamik hale getirilmesi

- Çalışan memnuniyetine ilişkin anketlerin düzenlenmesi ve değerlendirilmesi

- Ücret araştırmalarının yapılması ve iş tanımlarının hazırlanması

- Eğitim
değerlendirilmesi

- Personel seçimi ve oryantasyon

- Risk yönetimi

- Intranet ve diğer teknolojik destekler

- Bordro hizmetleri tutulması

- Özlük bilgilerinin derlenmesi ve kayitların
- İs analizlerinin yapılması

- Performans yönetimi sisteminin kurulması

- Müşteri memnuniyeti ölçümü

şeklindedir.

Yukarıdaki faaliyetlerin incelenmesinden de anlaşılacağı gibi, dışarıdan kaynak sağlayan firma anlaşmanın türüne göre çok sayıda çözüm üretebilmektedir. Firmanın personel politikası doğrultusunda personele ilişkin her tür bilgiyi toplayarak bir veri tabanı oluşturmaktadır. Alınan bilgilerin kapsamı verilecek hizmete göre farklıdır. Yine hizmetin kapsamı da taleplerle bağlantılıdır. Örneğin bordrolama işini diş kaynaklardan sağlayan bir firma yıl sonunda yapacağı zamların getireceği maliyeti öğrenip,bölümlere göre yapılacak farklı zam oranlarına göre birden fazla sayıda senaryo geliştirerek maliyetlerini hesaplayabilmektedir.

İnsan kaynakları konusunda hizmet veren firmalar, personeli kendi kadrosuna almakta, tüm yasal ve özlük işlerini kendileri gerçekleştirmektedir. Proje söz konusu elemanların temini işlemi ile başlatılmaktadır. Kendi portföyünden veya gazete ilanlarından seçilen ön adaylar arasından firmanın da onay verdiği elemanlar tedarikçi firmanın bordrosunda kadrolanmaktadır. Bunlar iş tanımlarında belirtilen işleri firma adına firmanın gösterdiği çalışma yerlerinde gerçekleştirmekte ve firmaya rapor etmektedir. Ay içinde firma tarafından saptanan maaş, prim, ikramiye, yemek ücreti, yol ücreti, masraf ve puantajlarına bağlı olarak bordrolar düzenlenmektedir. Çalışanlara ait yasal ödemeler için firma tedarikçi firmaya ödeme yapmakta ve bu işlemler kendi adlarına gerçekleştirilmiş olmaktadır. Tedarikçi firma temsilcileri, sorumlu olduğu firmalara düzenli ziyaretler yaparak, güncel mevzuat ve değişiklikleri bildirmekte,yllın belirli dönemlerinde yapılan vergi iadesi ve nema gibi ödemelerin yapılması ile ilgili olarak çalışanlara bilgi vermektedir.

Bazı firmalar kadrosuna aldığı personelin, kendisine ve ailesine ait vizite kayıtlarının hazırlanmasını ve kendilerine ulaştırmasını sağlamaktadır. Maaş artış dönemlerinde piyasada uygulanan politikalar hakkında bilgi toplayarak ve çalışmalara katılarak zam oranlarının tespitinde danışmanlık hizmetinin verilmesi,istenirse prim sistemlerinin düzenlenmesi ve geliştirilmesi,yıl sonlarında vergi iade ve nema tutarlarının hesaplanması ve elemanlara ödenmesinin sağlanması da yine bu firmalar tarafından gerçekleştirilmektedir.

İnsan kaynakları konusunda diş kaynaklardan yararlanan firmalar, aldıkları hizmet karşılığında ödedikleri bedeli hizmet bedeli olarak gider kaleminde değerlendirmeye alabilmekte ve doğrudan kardan düşebilmektedir. 


\section{INSAN KAYNAKLARI YÖNETIMINDE DIŞ KAYNAKLARDAN YARARLANMA KARARININ VERILLMESI}

Dış kaynaklardan yararlanma farklı sektörlerde kabul gören ve giderek daha fazla işi kapsamına alan bir kavram olarak karşımıza çıkmaktadır. Otomotiv, beyaz eşya, gıda, perakendecilik, konfeksiyon, inşaat, ilaç sektöründe diş kaynaklardan yararlanma hemen her işe uygulanabilmektedir: muhasebe, bilgi işleme sistemleri, ambalaj, depolama, yemek, taşıma, postalama, dağıtım, pazarlama, güvenlik, temizlik, ofis hizmetleri, otomobil kiralama, üretim, insan kaynakları vb.

İnsan kaynakları hizmeti veren firmaların müşterilerine çok geniş bir alanda hizmet verdikleri görülmektedir. Burada öncelikle önemli olan, insan kaynakları konusunda hizmet veren firmalardan yararlanılıp yararlanılmayacağı kararının verilmesidir. Dış kaynaklardan yararlanma firma açısından esneklik kazanma, hızlı karar alma, çekirdek kadro ile çalışmanın avantajlarından yararlanma,riski ve maliyeti azaltma ve kaliteyi arttırma ile gibi faydaları içermektedir [7]. Günümüzde "tüm işleri kendi bünyesinde gerçekleştirmeye çalışma" yerini giderek "temel yetenekleri üzerinde odaklaşarak, bunun dışında kalan faaliyetleri bu konuda uzmanlaşmış diğer firmalardan sağlayarak değer yaratması"na bıraktığı görülmektedir [7]. Bununla birlikte, diş kaynaklardan yararlanma kararının verilmesi üzerinde iyi düşünülmesi gereken bir karardır. Firmanın hangi konularda, hangi tedarikçiden,hangi koşullarda dış kaynaklardan yararlanacağının sağlıklı biçimde belirlenmediği durumda beklenen faydalar sağlanamayacaktır. Firmanın temel yeteneği kapsamındaki faaliyetlerin dış kaynaklardan sağlanmaya çalışılması, yanlış tedarikçinin seçimi ve sözleşmenin gerektiği gibi düzenlenmemiş olması firmanın mevcut avantajlarını da kaybetmesine neden olabilir.

Firmaların dış kaynaklardan yararlanma yoluna gitmeden önce vizyon ve misyon tanımlarını yapmış olmaları, bu tanımlamalarla uyumlu olarak bazı bilgi, beceri ve yetenekler üzerinde odaklaşmaları gerekmektedir. Bu şekilde hangi alanlarda dış kaynaklara başvurulması gerektiği, nelerin firma tarafından yapılması gerektiği ortaya çıkacaktır.

İhtiyaçlara birebir cevap veren, problem çözme yeteneği gelişmiş, finansal açıdan sağlam ve kültürel açıdan uyumlu tedarikçinin seçimi ve ilişkilerin düzenlenmesi de sistemin başarısı açısından önem taşır. Taraflar arasında yapılan anlaşmanın süre,garanti, performans ölçütleri, minimum hizmet seviyesi, ödül ve ceza konularına açıklık getirmesi gerekmektedir. Ayrıca tedarikçinin belirlenen hizmet seviyesine uyup uymadığının periyodik kontrolü de başarıyı arttıracaktır.
Daha önce de belirtildiği gibi; her ne kadar dış kaynaklardan yararlanma, maliyet indirimini hedeflese de, bu tarz uygulamalarda ana amaç maliyet olmamalıdır. Sadece maliyet göz önünde bulundurularak girişilen bir çaba kalite ve müşteri memnuniyetini tehlikeye sokacaktır. İnsan kaynaklarının firma dışına taşınması hizmet kalitesinin düşmesi ve çalışan memnuniyetinin azalması ile sonuçlanıyorsa, faaliyetin bir anlamı kalmayacaktır. Çalışanların tedarikçi firmaya karşı güvensizlik duyması veya tedarikçi firmanın ihtiyaçlarını karşılamayan kalıplaşmış çözümler sunması durumunda insan kaynaklarının etkin yönetimi imkansızlaşabilir.

İnsan kaynakları fonksiyonları arasında yer alan endüstriyel ilişkiler ve performans yönetiminde dış kaynaklardan yararlanılması konusunda bazı tereddütler mevcuttur. $\mathrm{Bu}$ fonksiyonların başarıyla yürütülmesinde ilişkilerde uzun dönemlilik, gizlilik ve güven büyük rol oynadığından, fonksiyonun dış kaynaklar aracılığıyla yerine getirilmesi problem yaratabilmektedir [5].

Gizliliğin korunması ihtiyacı ve süreçler üzerinde kontrolün kaybedilme ihtimali, firmaların, insan kaynaklarında dış kaynaklardan yararlanmaya ihtiyatlı yaklaşmalarını getirmektedir.

Tepe yöneticilerinin işe alma ve yerleştirilmeleri sürecinde, danışmanlık firmasının sadece aday havuzunu oluşturması, bunun dışındaki tüm safhaların firmanın kendisi tarafından gerçekleştirilmesi buna örnek olarak verilebilir. Yine bir çok firmanın ücret ve maaş araştırmalarını veya iş değerlendirmesini dış kaynaklardan sağlaması, ancak ücret ve maaş değişiklikleri, performans temelli ödüller vb. konuları firma içinde gerçekleştirmesi diğer bir örnektir [5].

\section{DIS KAYNAKLARDAN YARARLANMA KARARI: AKARYAKIT DAĞITIM SEKTÖRÜNDE BİR ÖRNEK OLAY INCELEMESİ}

Önceki bölümlerde teorik olarak, dış kaynaklardan yararlanmanın nedenleri, kapsamı ve dış kaynaklardan yararlanma kararının verilmesi açıklanmaya çalışılmıştır. Burada ise akaryakıt dağıtım sektöründe faaliyet gösteren ve ülkemizin en önde gelen firmalarından biri olan $X$ firmasının insan kaynakları faaliyetleri ve bu faaliyetlerin içinde dış kaynaklardan yararlanmanın seviyesi incelenecektir. Firmanın özellikle son üç yıl içinde gerçekleştirdiği büyüik değişim böyle bir incelemeyi daha anlamlı kılmaktadır.

Bu amaca yönelik olarak öncelikle firma hakkında genel bilgilere yer verilecek, daha sonra firmanın insan kaynakları süreçleri ele alınarak bunların hangilerinde dış kaynaklardan yararlanmanın tercih edildiği nedenleriyle birlikte ortaya konmaya çalışılacaktır. 


\section{V.1. Firma Hakkında Genel Bilgiler}

X firması 18 Şubat 1941 tarihinde kurulmuş olup, akaryakıt dağıtım ve pazarlama ve madeni yağ üretim ve pazarlama alanında faaliyet göstermektedir. 1990 yılında Özelleştirmesi amaciyla Özelleştirme İdaresi Başkanlığına bağlanmış olup, 21 Temmuz 2000 tarihinde İş-Doğan Petrol Yatırımları A.Ş.' ye Sirket Hisselerinin \%51'lik kısmı 1,260 milyon USD' 'ye devredilmiştir [8].

X firmasının özelleştirme öncesinde 3.800 çalışanı varken bugün itibariyle yaklaşık olarak 1.000 çalışanı mevcuttur.

Özelleştirilme sonrasında hemen yeniden yapılanma sürecine giren $\mathrm{X}$ firması öncelikle köklü geçmişine çağdaş ve modern çizgiler ekleyerek teknolojiyi hizmet kalitesiyle birleştirmek amaciyla öncelikle süreçlerin yeniden tasarımı yoluyla organizasyonel küçülme yoluna gitmiş fakat bu arada yatırımlarına devam etmiştir.

Özelleştirme öncesinde satışları genelde yoğun olarak kamu sektörüne olan X firması, toplumsal imajı büyük, hantal, sessiz, pasif ve demode,pazardaki pay1 azalan, istasyon standartları düşük, fazla personel istihdam eden olarak belirlenmiş olup, sektördeki rakipleri tarafından ciddiye alınmayan bir şirket olmuş fakat özelleştirme sonrasında büyük, dinamik, müşteri odaklı, şeffaf, agresif, proaktif ve yenilikçi olarak tanımlanan bir kuruluş haline gelmiş, sektörde pazar payı, verimliliği, ve istasyon standartları artan ve personel giderleri azalan bir kuruluş haline gelmiştir.

Akaryakıt Dağıtım Sektöründe yapılan yasal düzenlemeler neticesinde akaryakıt fiyatları otomatik fiyatlandırma mekanizması ile dünya fiyatları ile paralel hale gelmiş, ve sonrasında başka bir kararname ile pompa fiyatları bant sistemine geçilmiştir. Şu haliyle sektörde kamu tarafından belirlenen bir satış fiyatı olduğu için $X$ firması maliyetlere odaklanma yoluna giderek yeniden yapılanma sürecinde küçülme yoluna gitmiştir.

Yeniden yapılanma sürecinde gelişen küçülme faaliyetlerine örnek vermek gerekirse;

Daha önce kuruluş bünyesinde bulunan Gemi İşletme Müdürlügüü'nde 156 personel çalışmakta olup, bu bölümde çalışanlar 7 adet gemi ile Tüpraş, Ataş ve yurt dışı kaynaklarından tesisatlarına akaryakıt ikmali yapmaktadır. X firması yönetimi sektörde bulunan kuruluşlara kıyasla böyle bir tedarik yolunu hem maliyetli hem de fazlaca hantal olarak bulmuştur. Öncelikle gemileri satış yoluyla değerlendirip, sonrasında işletme müdürlüğünde çalışan personeli ise tensikat yoluyla işten ayırmıştır. Deniz yoluyla tedarik faaliyetleri ise Deniz ulaşım koordinatörü ve iki enspektör ile sağlanma yoluna gidilmiş piyasa rekabet koşulları çerçevesinde fiyatlarla tedarik sürecini seçmiştir.

Özelleştirme öncesinde varolan örgüt yapısını değiştirerek tamamen müşteri odaklı bir örgüt ile yeniden yapılanmıştır. Firmanın örgüt şeması aşağıda Şekil.1'de gösterilmektedir.

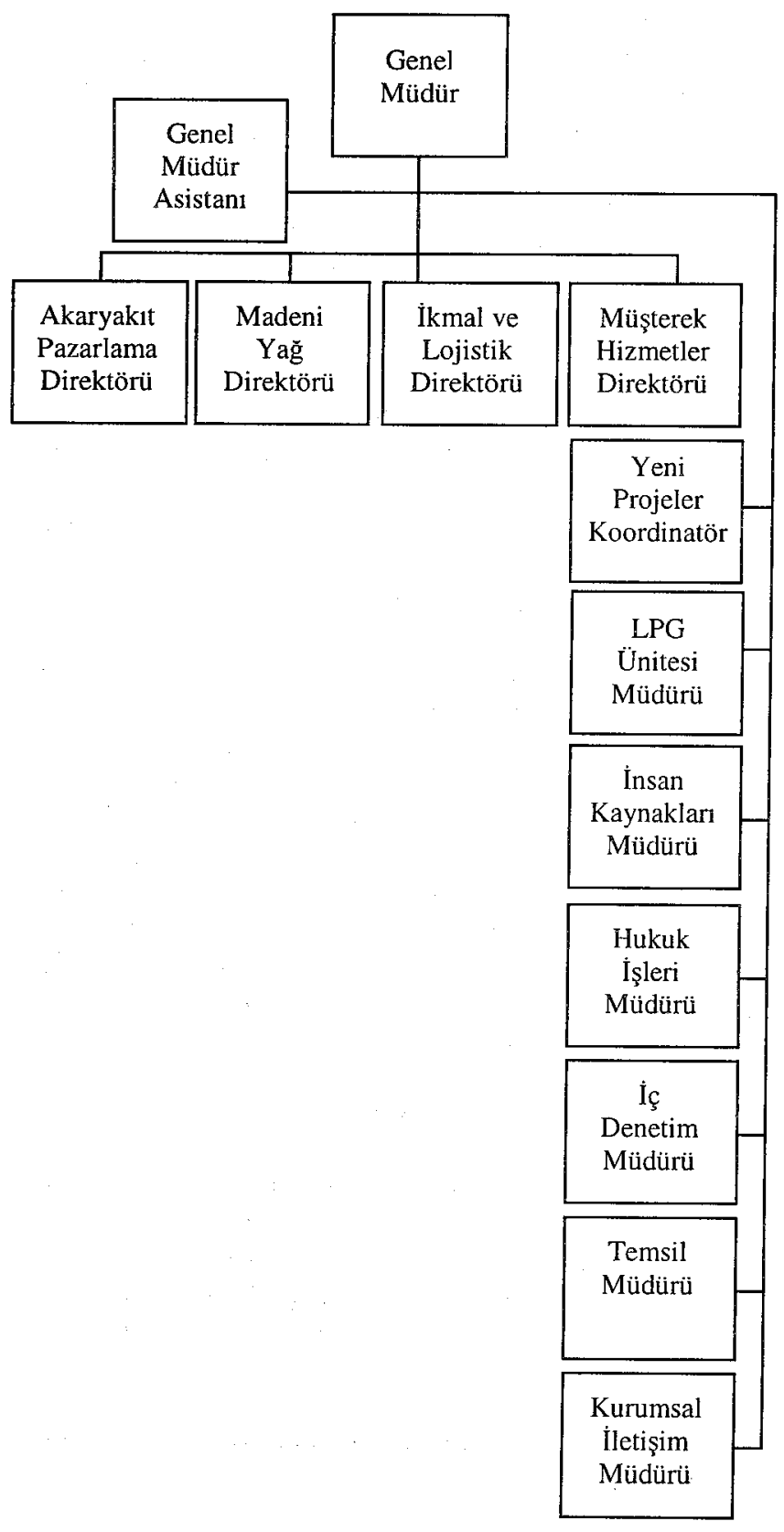

Şekil.1: X Firması Örgüt Şeması

2002 yılında örgüt yapısında yer alan direktörlüklerin talepleri doğrultusunda aşağıdaki örgüi değişiklikleri gerçekleştirilmiştir: 


\section{Akaryakut Pazarlama Direktörlüğ̈̈ talebi doğrultusunda;}

Ticari ve Endüstriyel Satışlar Müdürlüğü'nün görevleri arasında bulunan endüstriyel madeni yağ satışları, Madeni Yağ Direktörlügü'nde yeni oluşturulan Madeni Yağ Endüstriyel Satışları Müdürlüğü'ne devredildi. Ticari ve Endüstriyel Satışlar Müdürlüğü, Ticari ve Endüstriyel Yakıtlar Müdürlüğü adı altında yeniden yapılandırılarak sadece akaryakıt ürünlerine odaklanmış toptan satış ve pazarlama faaliyetlerini gerçekleştirecek bir birim haline getirilmiştir.

İstasyon Planlama Müdürlüğü ve Strateji ve Planlama Müdürlüğü birleştirilerek Akaryakıt Pazarlama Direktörü'ne doğrudan bağlı, Strateji ve İstasyon Planlama Müdürlüğü adı altında yeni bir birim oluşturulmuştur.

İstasyon Satışları Müdürlüğü altında, Bölgeler Müdürü'ne doğrudan bağlı ve sorumluluk alanı tüketici tanıma (AutoMatic) sistemini hedef müşterilere tanıtmak, sisteme yeni ve transfer müşteriler kazandırarak sadık müşteri kitlesi yaratmak olan Tüketici Tanıma Sistemleri Satış Müdürlüğü oluşturulmuştur.

İstasyon Satışları Müdürlüğü altında, Bölgeler Müdürü'ne doğrudan bağlı ve sorumluluk alanı ülke genelindeki istasyon ve bayileri yöneten Bölge Müdürleri'nin yanısıra, Tüketici Tanıma Sistemi, Direkt Akaryakıt Taşıması ve diğer projelerde Bölgeler Müdürü'ne destek vermek, performans verilerini derlemek, gelen bilgilerin standardizasyonunu ve analizini yapmak, yeni projelerde satı̧s birimini temsil etmek ve satış organizasyonuna destek veren merkez birimlerle koordinasyonu sağlamak olan Bölgeler Satış Koordinatörlüğü oluşturulmuştur.

\section{Madeni Yă̆ Direktörlüğü talebi doğrultusunda;}

Akaryakıt Pazarlama Direktörlüğüu, Ticari ve Endüstriyel Satışlar Müdürlüğü bünyesinden ayrılan endüstriyel madeni yağ satışları fonksiyonu, yeni oluşturulan ve doğrudan Madeni Yağ Direktörüne bağlı olan Madeni Yağ Endüstriyel Satışlar Müdürlüğüi'nün sorumluluğu altına verilmiştir.

\section{Müssterek Hizmetler Direktörlüğ̈̈i talebi doğrultusunda;}

Müşterek Hizmetler Direktörlüğü altında bulunan Ofis Yönetim Müđürlüğü doğrudan Genel Müdür'e bağlı bir müdürlük olmuştur.

Bilgi Sistemleri Müdürlügü fonksiyonlarına göre yeniden yapılandırılmıştır.

\section{Ikmal ve Lojistik Direktörlü̆ğï talebi doğrultusunda;}

İkmal ve Lojistik Direktörlüĭü, Lojistik Müdürlügü bünyesindeki Tesisat Ticaret Müdürlükleri, Müșterek Hizmetler Direktörlüğü, Muhasebe Müdürlügü'ne bağlı bulunan Tesisat Muhasebe Şeflikleri ile birleștirilerek, Muhasebe Müdürlügüu'ne bağlı Tesisat Muhasebe ve Faturalama Şeflikleri oluşturulmuştur.

$\mathrm{Bu}$ yapılanmanın ikinci bir örneği ise Insan Kaynakları Bölümünde gerçekleşmiştir. 21 Temmuz 2000 Tarihinde Personel Daire Başkanlığı'na bağlı birimlerde görev yapan toplam 325 personel bulunuyordu. $\mathrm{X}$ firması 'nın değişim hedefleri dogrultusunda modern İnsan Kaynakları uygulamalarını hayata geçirecek, yetkin ve etkili bir departman oluşturuldu. Ekibin tamamı, X firması İnsan Kaynakları Yönetimi'nde gerçek anlamda değişimi geçekleştirecek, konularında uzman, takım anlayışı içerisinde çalı̧̧an ve yetkin, yeni istihdam edilen kişilerden kuruldu. İnsan Kaynakları Müdürlüğü, temel yönetim felsefesini müşteri odaklı yaklaşım, sürekli gelişim, takım anlayışı ve üstün performans olarak belirledi. Departman kültürünün bir parçası olarak da bu kriterlerden asla taviz verilmeyeceğini benimsedi. Bir müdür, üç koordinatör, bir danışman, on uzman ve bir yönetim asistanı olmak üzere toplam on altı kişiden oluşması planlanan $\mathrm{X}$ firması İnsan Kaynakları Müdürlüğü, halen bir müdür, iki koordinatör, altı uzman ile toplam 9 personel ile hizmet vermektedir. İK departmanında örgüt şu şekilde gerçekleşmiştir [8].

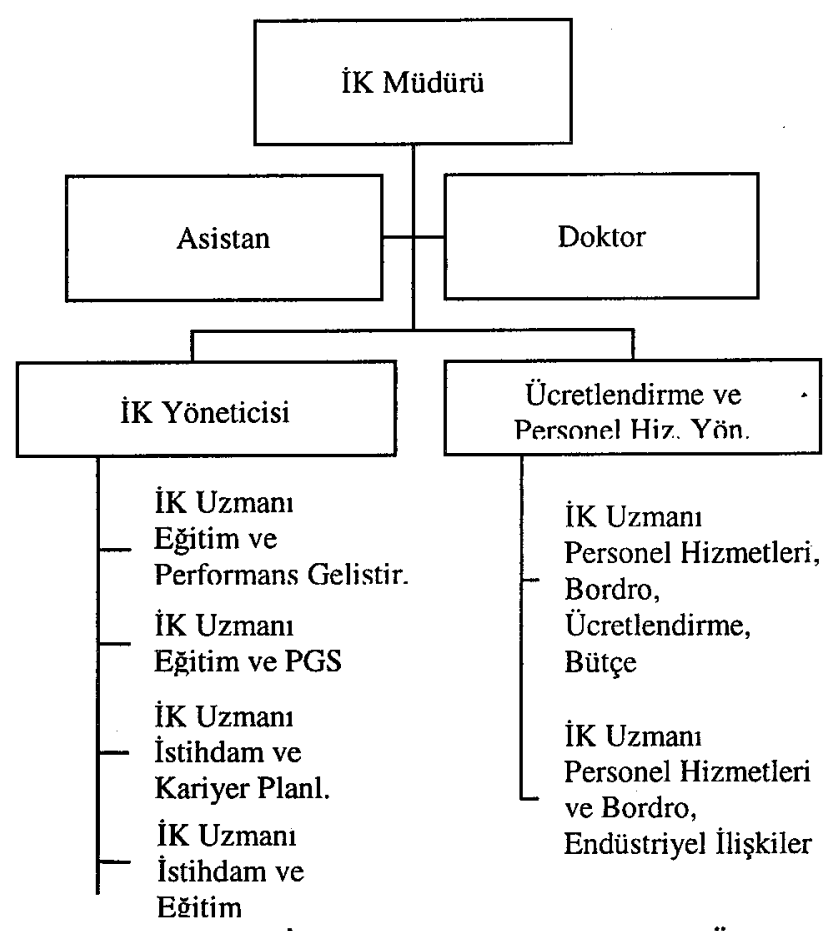

Şekil.2: X Firması İnsan Kaynakları Müdürlüğü Örgüt Şeması 


\section{V.2. İşe Alım Süreci}

\section{V.2.1. İşe Alınan Aday Sayısı}

X Firması 2002 y1lında 114 yeni personel istihdam etmiştir. Direktörlüklere göre işe alınan adayların dağılımı aşağıda Tablo. 1 üzerinde gösterilmektedir.

Tablo.1: Direktörlïklere Göre İşe Alınan Adayların Dağılımı

\begin{tabular}{|l|l|r|r|}
\hline & & Sayı & \multicolumn{1}{c|}{$\%$} \\
\hline \multirow{5}{*}{$\begin{array}{l}\text { Direktörlüklere } \\
\text { Göre İşe Alınan } \\
\text { Adaylar }\end{array}$} & $\begin{array}{l}\text { Akaryakıt } \\
\text { Pazarlama }\end{array}$ & 37 & 33 \\
\cline { 2 - 4 } & $\begin{array}{l}\text { Madeni } \\
\text { Yağlar }\end{array}$ & 14 & 12 \\
\cline { 2 - 4 } & $\begin{array}{l}\text { İkmal ve } \\
\text { Lojistik }\end{array}$ & 31 & 27 \\
\cline { 2 - 4 } & $\begin{array}{l}\text { Müşterek } \\
\text { Hizmetler }\end{array}$ & 26 & 23 \\
\cline { 2 - 4 } & $\begin{array}{l}\text { İnsan } \\
\text { Kaynakları } \\
\text { Md. }\end{array}$ & 4 & 3 \\
\cline { 2 - 4 } & $\begin{array}{l}\text { İç Denetim } \\
\text { Md. }\end{array}$ & 1 & 1 \\
\cline { 2 - 4 } & $\begin{array}{l}\text { Kurumsal } \\
\text { İletişim }\end{array}$ & 1 & 1 \\
\cline { 2 - 4 } & TOPLAM & $\mathbf{1 1 4}$ & $\mathbf{1 0 0}$ \\
\hline
\end{tabular}

\section{V.2.2. İşgücü Devir Oranı}

2002 yılında 114 yeni giriş, 258 çıkış, 144 terfi, 93 iș değişikliği, 25 kapsam değişikliği, 94 nakil gerçekleşmiştir. Buna göre 2002 y1lı personel devir oranı $\% 24$, işten ayırma devir oranı $\% 21$, istifa devir oranı ise $\% 2$ 'dir.

\section{V.2.3. Maliyetler}

İşe alım maliyeti, işe alım faaliyetinin etkinliğini maliyetler bazında ölçümlemek ve faaliyet performansını izlemek amacıyla hesaplanır. İşe alım maliyeti, direkt işe alım maliyetleri toplamının (diğer İK faaliyet giderleri hariç tutularak) belirli bir zaman aralığında işe alınan kişi sayısına oranıdır. İşe alım maliyeti yıl sonunda ölçümlenir [9].

İse Alım Maliyeti =

Direkt İşe Alım Maliyetler Toplamı

\section{İşe Alınan Kişi Sayısı}

Direkt işe alım maliyetler toplamı hesaplanırken aşağıdaki maliyet unsurlarını dikkate almak gerekir [9].

- İş duyurusu, iş ilanı maliyetleri,

- Danışman işe alımcı maliyeti,

- Danışmanlık gideri , komisyon maliyeti,

- Kariyer veya İş fuarları katılım maliyetleri,

- Aday yol masrafları

İşe alınan kişi sayısı ise belirli bir zaman aralığında işe alınan kişi sayısını ifade eder [9].

İşe alınan personel için ortalama kişi başına 688 milyon TL harcanmış, ayrıca işe alımın outsource maliyeti ise işe alınan bir kişinin yıllık maaşının \% $10+$ KDV olarak fiyat alınmış olup buna göre Yatırımın Geri Dönme Oranı hesaplanmıştır.

2002 Yilında:

İşe Alınan Aday Sayısı:

114

X Firması İșe Alım Maliyeti:

$688.000 .000 \mathrm{TL}$

Dış Kayn. İşe Alım Maliyeti:

2.542.000.000 TL

(Adayın Yıllık Brüt Maaşının (1.796.000.000*12) $\left.\% 10^{\prime} \mathrm{U}+\mathrm{KDV}\right)$

$\mathrm{ROI}=\frac{2.543 .000 .000-688.000 .000}{688.000 .000} \times 100=270$

Yukarıdaki veriler 1șığında bakıldı̆̆ında, bordro sürecinin İnsan Kaynakları Müdürlüğü tarafından $X$ Firması bünyesinde gerçekleştirilmesi sonucunda, şirketin yaptığı yatırım karşılığında elde ettiği kazanç; \% 270 oranında gerçekleşmiştir.

\section{V.2.4. İstihdam Sürecinde Geçen Süreler}

Başvurunun yapılmasından adayın işe başlama tarihine kadar geçen işe alım süreci hakkında bilgi edinilmesini sağlar. Ortalama işe alım süresini göstererek işe alım sürecinin gerek zaman gerekse performans açısından gözden geçirilmesini sağlar. Boş pozisyon doldurma süresi yıl sonunda ölçülür.

Boş Pozisyon

Doldurma

Süresi $=$

Firmada talebi karşılamada en uzun süre 86 gün iken (veritabanı yöneticisi pozisyonu), en kısa süre 3 gün (hava ikmal servis şefi pozisyonu) olarak gerçekleşmiştir. Talebin ortalama karşılanma süresi ise 22.3 gündür. 


\section{V.2.5. İstihdam Süreci İstatistikleri}

Firmanın insan kaynakları departmanının 2002 faaliyet raporunda yer aldığı şekliyle istihdam sürecine ilişkin veriler Tablo 2 'deki gibidir:

Tablo.2: İstihdam Süreci İstatistikleri

\begin{tabular}{|l|r|}
\hline İnternet üzerinden başvuru sayısı & 15,750 \\
\hline Dökülen CV sayısı & 2,585 \\
\hline $\begin{array}{l}\text { İgili tarafından olumsuz bulunan CV } \\
\text { sayısı }\end{array}$ & 718 \\
\hline $\begin{array}{l}\text { İgili pozisyon için mülakat kabul etmeyen } \\
\text { aday sayısı }\end{array}$ & 137 \\
\hline $\begin{array}{l}\text { Görïsşmeyi kabul ettiği halde habersiz } \\
\text { gelmeyen aday sayısı }\end{array}$ & 20 \\
\hline 1. Mülakat Sayısı & 975 \\
\hline 2. Mülakat Sayısı & 353 \\
\hline Toplam İşe Alınan Aday Sayısı & 115 \\
\hline
\end{tabular}

\section{V.2.6. İs Teklifini Reddeden Adaylar}

İş teklifini reddeden aday oranı, işe alım sürecinde şirketin tercih edilme oranını ve ücretlendirme politikalarının etkinliğini ölçer. Yıl sonunda hesaplanır [9].

İş Teklifini Red Eden Aday İş Teklifi Reddeden Sayısı Aday Oranı $=\quad$ Toplam İs Teklif Edilen Aday Sayısı

Tablo.3: Direktörlüklere Göre İş Teklifini Reddeden Adaylar ve Reddetme Nedeni

\begin{tabular}{|c|c|c|}
\hline $\begin{array}{l}\text { İș Teklifini Reddeden } \\
\text { Aday Sayısı }\end{array}$ & & 13 \\
\hline \multirow{5}{*}{$\begin{array}{l}\text { Direktörlüklere Göre } \\
\text { İş Teklifini Reddeden } \\
\text { Adaylar }\end{array}$} & Akaryakıt Pazarlama Dir. & 4 \\
\hline & Madeni Yağlar Dir. & - \\
\hline & İkmal ve Lojistik Dir. & 4 \\
\hline & Müşterek Hizmetler Dir.* & 4 \\
\hline & İnsan Kaynakları Md. & 1 \\
\hline \multirow{4}{*}{$\begin{array}{l}\text { İş Teklifini } \\
\text { Reddetme Nedeni }\end{array}$} & Ücret Yetersizliği & 9 \\
\hline & $\begin{array}{ll}\text { Başlama } & \text { Zamanı } \\
\text { Uyuşmażlığ } & \end{array}$ & 1 \\
\hline & $\begin{array}{ll}\text { Eski } & \text { Firmadan } \\
\text { Ayrilamama } & \end{array}$ & 1 \\
\hline & Çalışma Yeri Sorunu & 2 \\
\hline
\end{tabular}

*Müşterek Hizmetler departmanında iş teklifini reddeden adaylanı tamamı Bilgi İșlem bölümü adaylanıdır

Yukarıdaki tabloların incelenmesi sonucunda görüleceği üzere; 2002 yllında 13 kişi iş teklifini çeşitli nedenlerle reddetmiştir. Buna göre iş teklifini reddedenlerin oranı 13/114 yani \%11'dir.

\section{V.3. Eğitim Süreci}

Firma bünyesindeki eğitim bölümünün temel amacını, çalışanların görevlerinin gerektirdiği yetkinlik ve yönetim becerilerini geliştirmelerini sağlayarak, iş sonuçlarına gözlemlenebilir iyileştirmeler getiren eğitim programları hazırlamak olarak açıklamaktadır.

$\mathrm{Bu}$ amaçla 2002 Yilında firmada 30 eğitim programında toplam 848 Gün Eğitim verilmiştir.

Eğitim gün sayılarının direktörlüklere göre ayırımı Tablo.4'de verilmektedir.

Tablo.4 : Eğitim Gün Sayılarınn Direktörlüklere Göre Ayırım

\begin{tabular}{|c|c|c|}
\hline DÍREKTÖRLÜK & $\begin{array}{c}\text { Ë̈ITIM } \\
\text { G } \ddot{U} N \\
\text { SAYISI }\end{array}$ & $\begin{array}{c}E \check{G I T I M} \\
G \ddot{U} N / \\
K \dot{I} \dot{I}\end{array}$ \\
\hline Akaryakıt Pazarlama Direktörlüğü & 304 & 2.04 \\
\hline İkmal Ve Lojistik Direktörlüğü & 145 & 1.38 \\
\hline Madeni Yağ Direktörlüğü & 225 & 2.92 \\
\hline Müșterek Hizmetler Direktörlüğü & 121 & 1.30 \\
\hline Diğer Bölümler & 53 & 1.61 \\
\hline X Firması Geneli & 848 & 1.85 \\
\hline
\end{tabular}

Eğitim programlarının türü,süresi ve tekrar sayıları aşağıda Tablo.5 'de verilmektedir.

Tablo.5: 2002 Yılında Gerçekleştirilen Eğitim Programları

\begin{tabular}{|l|c|c|}
\hline $\begin{array}{l}\text { EĞİṪM } \\
\text { PROGRAMI }\end{array}$ & $\begin{array}{c}\text { PROGRAM } \\
\text { SÜRESİ } \\
\text { (GÜN) }\end{array}$ & $\begin{array}{c}\text { PROGRAM } \\
\text { TEKRAR } \\
\text { SAYISI }\end{array}$ \\
\hline $\begin{array}{l}\text { Temel Yönetim } \\
\text { Becerileri }\end{array}$ & 4.5 & 2 \\
\hline Satışta Profesyonellik & 2.5 & 4 \\
\hline Etkili İletişim & 2 & 3 \\
\hline Esnek Satıcı & 2 & 1 \\
\hline Etkin İnsan Yönetimi & 2 & 2 \\
\hline İleri Sürüş Teknikleri & 2 & 6 \\
\hline $\begin{array}{l}\text { Etkin Yönetim ve } \\
\text { Etkin Yaşam }\end{array}$ & 2 & 2 \\
\hline Biz Kazanan Takımız & 1 & 1 \\
\hline Mülakat Teknikleri & 2 & 3 \\
\hline $\begin{array}{l}\text { Evet'e Doğru } \\
\text { Müzakere }\end{array}$ & 2 & 2 \\
\hline $\begin{array}{l}\text { Performans Geliştirme } \\
\text { Sistemi }\end{array}$ & 2 & 3 \\
\hline Çok Boyutlu Düşünme & 2 & 1 \\
\hline
\end{tabular}

* Ortalamalar, Performans Geliştirme Sistemine dahil olan 457 çalışan üzerinden hesaplanmıştır.

Firma eğitim konusunda farklı danışmanlık firmalarından hizmet almakta; bu çerçevede ağırlıklı olarak dört farklı danışmanlık firması ile çalışmaktadır. 
Eğitim programlarının başarısı da İK departmanı tarafından titizlikle takip edilmekte, departman yıllık faaliyet raporlarında ilgililerle paylaşılmaktadır.

2002 Yılı Eğitim Maliyetleri planlanan bütçe içerisinde gerçekleştirilmiştir. Yıl içi gerçekleştirilen eğitim programlarının maliyeti Tablo.6'da gösterilmektedir.

Tablo.6: 2002 Yılı İnsan Kaynakları Müdürlüğü Eğitim Bölümü Maliyetleri

\begin{tabular}{|l|c|}
\hline Eğitim Şirketlerine Ödemeler & 51.4 Milyar TL \\
\hline $\begin{array}{l}\text { Eğitim Bölümü Çalışanlarına Ait } \\
\text { Yıllık Maaş Maliyetleri }\end{array}$ & 33.5 Milyar TL \\
\hline Diğer & 2.2 Milyar TL \\
\hline Toplam Eğitim Maliyeti (Yıllık) & 87.1 Milyar TL \\
\hline
\end{tabular}

\section{V.4. İş Değerlendirmesi Süreci}

$\mathrm{X}$ firması A.Ş. bünyesindeki tüm kapsam içi işler ile iş grubu 8'e kadar olan işler Ağırlıklı Faktör Puan Mukayese Metodu ile değerlendirilmiştir. Söz konusu metot Ocak ayında geliştirilmiş ve pilot uygulaması Şubat ayında Atatürk Hava İkmal Müdürlüğü'nde denenmiştir. Pilot uygulamanın başarıya ulaşmasının ardından, 28 Şubat 2002 tarihinde yönetimin onayı alınarak iş değerlendirme sistemi tüm örgütü kapsayacak şekilde uygulamaya konmuştur.

1 Mart - 31 Temmuz 2002 tarihleri arasında yapılan saha ve değerlendirme çalışmalarında:

- 22 iş günü harcanarak 17 işyeri ziyareti yapılmıştır. edilmiştir

- Yaklaşık 300 görüşme sonucunda 177 iş analiz

- İș analizleri sonucunda 177 görev tanımı yazılarak ilgili birimlerden mutabakat alınmıştır.

- Söz konusu 177 iş, 12 iş günü harcanarak değerlendirilmiştir.

- Yapılan iş değerlendirilmeleri, ilgili direktörlük temsilcilerinin de katılımı ile yeniden gözden geçirilmiş ve mutabakat sağlanmıştır.

- Proje sonucunda 395 kapsam içi, 188 kapsam dișı olmak üzere toplam 583 personelin işi değerlendirilmiştir.

İş değerlendirme çalışmalarının ardından ücret dönüştürme modeli kurulmuş ve ücret senaryoları geliştirilmiştir. İş Değerlendirme Projesi sonucunda elde edilecek bulgular ve geliştirilen öneriler 2003 yılı başında yönetime sunulacak ve yönetimin vereceği karar doğrultusunda, şirket genelinde dile getirilen ücret dengesizliği problemlerini çözecek uygulamalar hayata geçirilecektir.

İş değerlendirmesi projesinin toplam maliyeti yaklaşık 11. Milyar TL (6,700.-USD, 6,400.-Euro) olarak gerçekleşmiştir. Söz konusu proje için bir danışman firmadan alınan teklif 40.000 ila 60.000.-Euro arasında değişmektedir. $\mathrm{Bu}$ verilere göre, iş değerlendirme projesini şirket bünyesinde gerçekleştiren Insan Kaynakları Müdürlüğü'nün projeye yapmış olduğu yatırımın şirkete sağladığı ekonomik kazanç (ROI), danışman firma ortalama maliyeti 50,000.-Euro kabul edilirse, \%681'dir.

\section{V.5. Ücret Araştırmaları}

Ücretlendirme ve Personel Hizmetleri Birimi, 2003 yılında ücret araştırmalarından daha etkin bir şekilde yararlanabilmek için 2002 yılında da çalışmış oldukları iki önde gelen danışmanlık şirketiyle çalışmalarını devam ettirmiştir.

$X$ firması ücretlendirme sisteminin $Y$ ve $Z$ Danışmanlık Firmaları'nın datalarıyla entegre hala getirilmesi için 2003 yılı içerisinde $X$ firması, bu firmaların datalarının tek tek kıyaslanarak karşılaştırma veritabanı kurulması hedeflenmiştir.

2002 yılı Y Danışmanlık Firması ücret araştırma anketi ilk defa internet üzerindeki anket formu doldurularak hazırlanmıștır. Ankette 90 kadro (168 kişi) ücret datası verilmiş olup $\mathrm{X}$ firması ücretlendirme politikaları ile ilgili sorular yanıtlanmıştır.

Z Danışmanlık Firması yetkilileriyle daha fazla ücret bilgisinin karşılıklı paylaşılması için görüşmeler yapılmış ve $\mathrm{X}$ firması olarak Z Danışmanlık Firması ücret araştırması için 104 adet pozisyona ait ücret datası verilmiş olup $\mathrm{X}$ firması ücretlendirme politikaları ile ilgili sorular yanıtlanmıştır.

Z Danışmanlık Firması Toplam Ücretlendirme Anketi 2002' ye bu sene $X$ firması dişında dört adet petrol dağıtım şirketi katılmış olup $Z$ Danışmanlık Firması ile yapılan görüşmeler sonucu $X$ firmasına özel pozisyon spesifik sektör raporunun hazırlanması talep edilmiştir. Böylece özellikle petrol sektöründeki ücretler hakkında spesifik ve detaylı veriler elde edilmiş olacaktır.

Ayrıca $\mathrm{X}$ firması ücretlendirme sisteminin, $\mathrm{Z}$ Danışmanlık Firması Point sistemi ve Y Danışmanlık Firması Global Grading Sistemi ile etkin bir şekilde karşılaştırabilmesi için, söz konusu firmalar'dan jenerik görev tanımları alınmış ve $X$ firması referanslarıyla karşılaştırma çalışmaları sonuç aşamasına gelmiştir. 
Buradan elde edilecek veriler 2003 yllında X firması iş değerlendirme sistemi ile entegre edilerek ücretlendirme sisteminin doğruluğu ve tutarlılığı pekiştirilecektir.

\section{V.6. Bordro Süreci}

2002 yılında 19.300 adet bordro yapılmıştır. Yapılan bu bordroların türleri ve sayıları aşağıda belirtilmiştir.

- 13.900 adet maaş bordrosu

- 3.900 adet avans bordrosu

- 241 adet kıdem tazminatı bordrosu

- 1.260 adet diğer bordrolar

$\mathrm{X}$ Firmasında iki uzman tarafindan gerçekleştirilen bordro hizmetlerinin birim maliyeti 1.17 \$'dır. Outsource Firmalanının bordro teklifleri ise çeşitlilik göstermektedir. Buna göre; bordro başına; A Danışmanlık Firması: 3,22\$, B Danışmanlık Firması: 3,57\$, C Danışmanlık Firması: 5,90\$ teklif vermişlerdir.

\section{V.7. Performans Geliştirme Süreci}

Firmada Performans Geliştirme Sistemi ile bireysel performansların geliştirilmesi yoluyla yüksek performansl, kazanan bir kurum kültürü yaratılması amaçlanmaktadır. Sistemin özünde çalışanların geliştirilmesinin hedeflendiği "performans geliştirme" kavramiyla vurgulanmaktadır.

2001 Yll Eğitim Performans Değerlendirme Sözleşmeleri bütün birimlerden toplanarak veri tabanına işlenmiştir. Ücretlendirme bölümü için formların analizi ve raporlaması yapılmıştır. 2001 Yılı Performans Değerlendirmelerinde belirtilen eğitim ihtiyaçları doğrultusunda 2002 Yılı Eğitim Programları belirlenmiştir.

X firmasında Performans Geliștirme Sürecinin hızlı bir şekilde çalışmasını sağlamak, etkinliğini arttırmak ve istenilen tüm analizlere en doğru şekilde ulaşmak amacıyla Şirket intraneti üzerinde çalışan e performans sistemi geliştirilmiştir. Bu projede SFS - Man Firması ile ortak çalışılmaktadır.

E-performans, Performans Geliştirme Sürecindeki kayıtların Şirket intraneti üzerine işlendiği ve burada tutulduğu bir sistemdir. E - performans sistemi sayesinde performans süreci kağıtsız bir ortamda gerçekleşmekte, istenilen belge ve analizlere en hizlı şekilde ulaşılabilmektedir.
E-performans Sistemi sayesinde tüm çalışanlar kendilerine özel olan şifreleri ile sisteme bağlanarak hedeflerini aktif olarak takip edebilmektedirler. Şirket yöneticileri şahsi formlarının yanı sıra kendilerine bağlı olan tüm çalışanların formlarını ve hedeflerini izleyebilmektedirler.

E-performans değerleme süreci ile firmada;

- Yaşanan zorlukları teknolojinin eriştiği noktayı kullanarak aşılması,

- En hızlı şekilde performans değerlendirme sürecini tamamlanması,

- En doğru raporlara kısa bir sürede ulaşılması,

- Çalışanların yetkinlik gelişimlerini etkin şekilde kontrol edilerek, firmanın verimlilik artışına katkıda bulunulmasıdır.

E-performans Sistemi kullanılarak firmada kişilere, departmanlara ve şirket geneline göre başarı ortalamaları istatistiksel raporlar halinde elde edilmektedir. Çalışanlara ait yetkinlik düzeyleri takip edilerek, Kariyer Geliştirme Sistemine veri sağlanmaktadır. Ücretlendirme bölümü için performans değerlendirme sonuçları raporlanmaktadır. Kişilere, departmanlara, şirket geneline göre yetkinlik seviyeleri gösterilmektedir. Geçmiş dönem karşılaştırmaları otomatik olarak elde edilmektedir. Tüm çalışanlar kendilerine ait hedefleri, yöneticiler kendilerine bağlı olan çalışanların hedeflerine istedikleri an ulaşabilmektedir. Eğitim ihtiyacı listeleri belirlenen kriterlere göre otomatik olarak hazırlanabilmektedir. Performans değerlendirme formunda talep edilen eğitim listeleri raporlanabilmektedir. Tüm süreç 2 hafta gibi kısa bir sürede tamamlanması mümkün olup, kağıt form basımı, dağıtım, geri toplama ihtiyacını ortadan kaldırmaktadır. Form doldurmayanlara veya eksik dolduranlara otomatik e-mail uyarısı yapilabilmekte ve raporlanıp telefon ile uyarı listesi ulaştırılmaktadır.

\section{V.8. İnsan Kaynakları Bölüm Faaliyetlerinin Performans Ölçütleri}

Firmanın 2002 yılı İK faaliyetleri verim ve performans metrikleri bazında incelenmiş ve aşağıdaki sonuçlara ulaşılmıştır

\section{V.8.1. İk Genel Destek Oranı}

İnsan Kaynakları Bölümü çalışanlarının tüm çalışanlara oranı başka bir deyişle bir İnsan Kaynakları Bölümü çalışanının kaç personelden sorumlu olduğunu göstermektedir. 
IK Genel Destek Oranı $=\frac{\text { Şirket Çalışan SayıIII }}{\text { |K Çalışan SayıIsı }}=\frac{1083}{12}=90,25$

\section{V.8.2. İk Harcama Oranı}

2002 yllinda ücret ve sosyal haklar dahil ÍK harcamaları ve faaliyet giderleri IK personeli bassına 73.066 milyon TL. olmuştur.

IK Harcama Oranı $=\frac{\text { Tüm IK Giderlerı }}{\text { |K Çalışan Sayısł }}=\frac{876.800}{12}=73$ Milyar TL

\section{V.8.3. İk Operasyonel Harcama Yüzdesi}

2002 yılında İK faaliyet giderleri toplam şirket faaliyet giderlerinin \%0.93'ü kadar olmuștur. Bu oran bize 'ÍK' nın operasyonel etkinliğini göstermektedir.

IK Operasyone IHarc. $\%=\frac{\text { IK Giderleri }}{\text { Şirket Operasyone IGiderleri }}=\frac{1.130 .228}{120.925 .835}=\% 0,93$

\section{V.8.4. Kişi Başı Ortalama Ücret, Gelir Ve Kar}

2002 yılında X firması çalışanı başına şirket geliri 5.874 milyar TL olmuştur. Başka bir deyişle bir $\mathrm{X}$ firması çalışanın 2002 yılında şirket gelirine katkısı 5.874 milyar TL olmuştur

KişiBaşı Ort. Gelir $=\frac{\text { Toplam Şirket Gelirleri }}{\text { Personei sayısı }}=\frac{6.361 .843}{1083}=5.874 \mathrm{milyar} \mathrm{TL}$

2002 yılında çalışan başına düşen yıllık kar oranı 212.514 milyar TL dir.

Kişı Başı Kar $=\frac{\text { Net Kar }}{\text { Personel sayısı }}=\frac{230.153 .485 .015 .260}{1083}=212.514$ Milyar TL

\section{V.8.5. Ücretlendirme Gelir Yüzdesi}

2002 yılında $\mathrm{X}$ firmas1, toplam gelirlerin \% 0,53 'ünü ücretlere harcamıştır.

Ücretlendirme Gelir \% $=\frac{\text { Toplam Ücretler }}{\text { Şirket Geliri }}=\frac{34.068 .282 .433 .239}{6 \cdot 361 \cdot 843.174 .720 .400}=\% 0.53$

\section{SONUÇ}

Firmalar, eskiden farklı olarak tüm işleri kendi bünyelerinde toplamamakta, bunun yerine temel yetenekleri üzerinde odaklaşarak diğer işleri uzman firmalar aracılığıyla gerçekleştirmektedir. Bilinçli bir faaliyet olarak diş kaynaklardan yararlanma belirli konuları ön plana çıkarmaktadır. Her şeyden önce firmada, hangi konuda diş kaynaklardan yararlanılması gerektiği belirlenmelidir. Diş kaynaklardan temin edilmesine karar verilen hizmet temel yetenek kapsamında olmamalıdır. Diğer deyişle bir firmanın kendisine uzun dönemli rekabet avantajı sağlayacak, kolayca taklit edilemeyen uzun dönemli bilgi,beceri ve yeteneklerini doğrulukla belirlemesi ve tüm çabasını burada yoğunlaştırılması gerekmektedir. Diş kaynaklardan yararlanmanın çok sayıda fayda içerdiği ve geleneksel örgüt yapılarından çağdaş örgüt yapılarına geçişi sağladığı muhakkaktır. Ancak neyin firma bünyesinde neyin "dışarıda" yapılacağının hatalı belirlenmesi firmanın gerilemesine ve yok olmasına neden olabilir.

Diş kaynaklardan yararlanma işletmenin hemen tüm faaliyetlerini kapsamakta, firmalar geniş bir perspektifte uzmanlaşmış firmalarla değer yaratma sürecinde bir arada hareket etmektedir. İnsan kaynakları fonksiyonuna ilişkin faaliyetlerin firma dişından, bu işi temel yetenek olarak benimsemiş olan firmalar tarafından gerçekleştirilmesi de diş kaynaklardan yararlanma uygulamalarının bir boyutudur.

İnsan kaynakları yönetimi çerçevesinde gerçekleştirilen çok sayıda faaliyet mevcuttur. Bilindiği gibi özellikle son dönemde insan kaynakları bölümünün rol ve sorumluluklarında önemli değişiklikler meydana gelmiş, faaliyet kapsamı giderek genişlemiştir. Çağın gereklerini yakalamak zorunda olan firmalar, artan rekabetin de etkisiyle insan kaynağını etkin kullanma ve geliştirme gereğini daha fazla hissetmiştir.

İnsan kaynakları departmanlarının giderek artan rol ve sorumluluğu nasıl gerçekleştirecekleri, bu konuda mevcut uzmanlaşmış firmaların desteğinden yararlanıp yararlanmayacakları, hangi oranda yararlanacakları önemli bir konudur. Kanımızca tüm diğer fonksiyonların dış kaynaklarca sağlanmasında olduğu gibi burada da önemli risk ve firsatlar söz konusudur.

Firma insan kaynaklarında dıș kaynaklardan yararlanma kararı vermeden önce istek ve ihtiyaçlarını doğru biçimde belirlemeli, alternatif maliyetleri hesaplamalı, tüm süreçlere ilişkin olarak etkinlik ölçümlerini yapmalı ve bunları kıyaslama yoluna gitmelidir. Doğru tedarikçinin seçimi ve tedarikçi ile uzun dönemli ilişkilerin etkin yönetimi de yine dış kaynaklardan yararlanmanın başarısını etkileyecektir. Firma insan kaynaklarını daha etkin hale getirme sürecinde, dış kaynaklardan yararlanmayı dikkatli biçimde uygulamalıdır.

Akaryakıt dağıtım sektöründe faaliyet gösteren ve ülkemizin önde gelen firmalarından birinde gerçekleştirilen inceleme, firmaların, belirtilen konuya titizlikle yaklaştığını göstermektedir. Söz konusu firmada tüm insan kaynakları süreçlerinin mevcut ve alternatif maliyetleri hesaplanmakta, süreçlerin performansı ölçümlenmektedir. Firma süreçlerinin etkinliğini, dünya çapında kullanılan ölçüm ve performans göstergelerine 
göre değerlendirmekte, sektördeki rakip firmalarla kıyaslamaktadır.

Firma işe alım, bordrolama iş değerlendirme faaliyetlerini kendi bünyesinde gerçekleştirmeyi tercih ederken, eğitim konusunda diş kaynaklardan yararlanmaktadir. Yine firma idari hizmetler kapsamındaki (haberleşme, evraklama ve arşiv, yemekhane hizmetleri, teknik destek (telefon,... elektrik), ofis-kırtasiye işlemleri, temizlik hizmetleri, otel ve konaklama organizasyonu, şirket araçlarının takibi)işlerde dış kaynaklardan yararlanmaktadır. $\mathrm{Bu}$ işlemlerin koordinasyonu ise firma bünyesindeki Personel Hizmetleri tarafından gerçekleştirilmektedir. Ücret araştırmaları konusunda da firmanın dış kaynaklardan yararlanmayı tercih ettiği ve bu konuda farklı danışmanlık firmalarının hizmetinden yararlandığı görülmektedir. Firmada performans geliştirme sürecinin hızlı bir şekilde çalışmasını sağlamak, etkinliğini arttırmak ve istenilen tüm analizlere en doğru şekilde ulaşmak amacıyla geliştirilen firma intraneti üzerinde çalışan e-performans sistemi projesinde ise önde gelen danışmanlık firmalarından biriyle ortak çalışılmaktadır.

Firmanın dış kaynaklardan yararlanmayı tercih etmediği süreçlerde bu sürecin firma içinde gerçekleştirilmesinin daha düşük maliyet yarattığı, bu maliyetin dışarıdan hizmet alınması durumunda hizmetin türüne bağlı olarak \% 200- \%600 oranında maliyet artışının ortaya çıkacağı görülmektedir. Burada maliyet önemli olmakla birlikte kuşkusuz kararın alınması sırasındaki tek belirleyici olmamalıdır. Sadece daha düşük maliyetli olduğu için dış kaynaklardan yararlanmak veya kararın alınmasında sadece maliyet unsurunu göz önünde bulundurmak hatalı sonuçlar doğuracaktır.

Tüm fonksiyonların olduğu gibi insan kaynakları fonksiyonunun dış kaynaklardan sağlanması kararı da firmanın, vizyonu- misyonu ile uyumlu biçimde verilmeli, dış kaynak dikkatlice belirlenmeli ve ilişkiler özenle sürdürülmelidir.

\section{YARARLANILAN KAYNAKLAR}

[1] HARKINS, P.; BROWN, S., "Shining new light on a growing trend", HR Magazine, December, 1995, s.75-79.

[2] DYSART, J.; "Kick Your System Outside", HR Magazine, August 1999, s.119-120.

[3] "Outsourcing HR", Business Europe, September 1999, s.1-3.

"What You Need To Know Now About Outsourcing HR Functions", HR Focus, October 2000, s.7,10.

[4] "12 Ouestions to Ask When Making the HR Outsourcing Decision" , Ioma's Report on Managing Information Systems, January 2002,s.5-6.

[5] GREER, C.R.; YOUNGBLOOD, S.A.; GRAY, D.A., "Human resource management outsourcing: The make or buy decision", Academy of Management Executive, 1999, Vol. 13, No:1, s.88.

[6] "Outsourcing'i Büyüten 3 Etken", Capital Digital, Ekim, 2002, s. 10 .

[7] ATAMAN, G., İşletme Yönetimi: Temel Kavramlar \& Yeni Yaklaşımlar, 2. Baskı, Türkmen Kitabevi, İstanbul, 2002.

[8] X firması A.S. 2001 İnsan Kaynakları Faaliyet Raporu, İstanbul (Dahili)

[9] FITZ-ENZ, J., How To Measure Human Resources Management ,2nd Edition, Mc Graw Hill, New York, 1995, s.45-89.

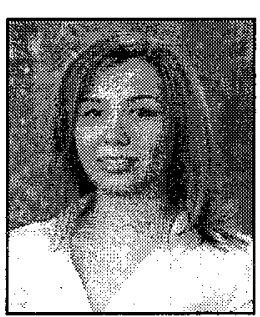

\section{Göksel ATAMAN}

Marmara Üniversitesi, İ.I.B.F.

Ressam Namı İsmail Sk. No.1 Bahçelievler - ISTANBUL

Tel: +90 (212) $5079925-1419$ gataman@marmara.edu.tr

Göksel ATAMAN has Ph.D. of Management and Organization at Marmara University Social Sciences Institute. She is Associate Professor in Management and Organization at Marmara University. She is Head of International Quality Management Department at Marmara University. Her research areas are organization theory and design, new management techniques, organizational culture, organizational behavior, and crisis management. 